\title{
Dīvānu Lugāti’t-Türk’te yer alan kumaş terimleri ve kelime kökenleri üzerine bir değerlendirme
}

\section{Sümeyra ALAN ${ }^{1}$}

\begin{abstract}
APA: Alan, S. (2020). Dīvānu Lugāti’t-Türk’te yer alan kumaş terimleri ve kelime kökenleri üzerine bir değerlendirme. RumeliDE Dil ve Edebiyat Araştırmaları Dergisi, (20), 23-42. DOI: 10.2900o/rumelide.791077.
\end{abstract}

\section{$\ddot{O} \mathbf{z}$}

Zengin bir kelime haznesine sahip olan Türkçenin tarihî ve modern devirlerindeki dil incelemelerinde söz varlığı üzerinde yapılan çalışmalar önemli bir yere sahiptir. Yapılan bu tarz çalışmalarla o toplumun toplumsal özellikleri, siyasi ve sosyal yaşam tarzı, gelenek ve görenekleri, kültür düzeyi hakkında geniş veriler elde edilmektedir. Türk toplumunda kumaşın mühim bir yeri vardır. Bu kumaşlarla şekillenen kıyafetler yöreden yöreye, bölgeden bölgeye farklılı göstermekte olup her bölgenin yahut yörenin sosyal mevkîsini, gelenek göreneklerini belirleyen bir giyim tarzı bulunmaktadır. Bu giyim tarzı oluşturulurken kullanılan kumaş türleri gösterdiği çeşitlilik bakımından incelenmeye değer görülmüştür. Çalışmamıza konu olan, Kâşgarh Mahmûd’un XI. yüzyılda kaleme aldığg ve Türkçenin bilinen ilk sözüğü olan Dīvānu Lugāti’t-Türk, söz varlı̆̆ı açısından zengin bilgiler sunmaktadır. Bu çalışmada Dīvānu Lugāti't-Türk’te yer alan kumaş terimleri ile ilgili söz varlığı taranmış, kelimelerin etimolojik tahlilleri farklı sözlüklerden faydalanılarak ayrıntılı bir şekilde verilmiş, ödünçlenen ve ödünçlenmiş olması muhtemel görülen kelimelerin kaynak dilleri tablo halinde sunulmuştur.

Anahtar kelimeler: Dīvānu Lugāti’t-Türk, kumaş terimleri, söz varlığı, etimoloji

\section{Fabric terms in the Dīwān Luyāt Al-Turk and an evaluation on word origins}

\begin{abstract}
The study of the presence of words in the historical and modern eras of the Turkish language, which has a rich vocabulary, has an important place. In this way, the social characteristics of the society, political and social lifestyle, traditions and customs, culture level is obtained from extensive data. Fabric has an important place in Turkish society. The clothes shaped by these fabrics vary to region, vary from region to region, and each region has a clothing style that determines the social position and traditions of the region. The fabric types used in creating this style of clothing were worth considering in terms of their diversity. Dīwān Luүāt al-Turk which written in the 11th century by Mahmûd al-Kâshgarî, the subject of our study and the first known dictionary of Turkish, which contains rich information in vocabulary of 11th century of Turkish. In this study, the presence of words related to the fabric terms $D_{\bar{I}}$ ān Luүăt al-Turk were surveyed, the etymological analysis of words was given in detail using different dictionaries, and their source orgins in which the words are loaned or are likely to be loaned are presented in a table.
\end{abstract}

Keywords: Dīwān Luүāt al-Turk, fabrics terms, vocabulary, etymology

1 Ars. Gör., Erzurum Teknik Üniversitesi, Edebiyat Fakültesi, Türk Dili ve Edebiyatı Bölümü (Erzurum, Türkiye), sumeyra.alan@erzurum.edu.tr, ORCID ID: 0000-0002-4406-2022 [Makale kayıt tarihi: 05.07.2020-kabul tarihi: 20.09.2020; DOI: 10.29000/rumelide.791077] 


\section{Giriş}

Söz varlığı, sadece bir dilde birtakım seslerin bir araya gelmesiyle kurulmuş simgeler, kodlar- ya da dilbilimdeki terimiyle göstergeler- olarak değil, aynı zamanda o dili konuşan toplumun kavramlar dünyası, maddî ve manevî kültürünün yansıtıcısı, dünya görüşünün bir kesiti olarak düşünülmelidir, diyen Aksan'a göre söz varlığı o dilin tarihine geniş ölçüde ışık tutmakta, yüzyıllar boyunca ortaya çlkan ses, biçim, söz dizimi ve anlam değişikliklerini yansitmakta, hangi dilerin etkisiyle, ne türden değişimlerin gerçekleştiğini göstermektedir (Aksan, 2004: 7-11). Temel söz varlığı ise insan organ adları, esas hareketleri ifade eden fiiller, öncelikli ihtiyaç maddelerini karşılayan kelimeler, sayı isimleri, akrabalık isimleri gibi sözleri kapsamaktadır. İnsan için birinci derecede önemli olan ve zaman içinde de çok az değişikliğe uğrayan bu kelimeler, çekirdek kelimeler olarak da adlandırılır (Şahin, 2006: 124). Günlük hayatın vazgeçilmezi olarak kullanılan, temel ihtiyaç maddelerinden sayılan, kültürün aktarıcısı olan kıyafetler toplumu yansıtan birer ayna gibidir. Aynı ülkenin farklı bölgelerinde geleneklere göre şekillenen bu kültür aynaları; üretildiği kumaşlardan seçilen renklere, sunulan modellerden işlenen desenlere kadar toplumun kimliğini ifade etmektedir. Kıyafetlerin temel parçası olan kumaşlar gerekse bir statü göstergesi gerek zenginlik ifadesi gerek bireyin kimlik göstergesidir.

Büyük Türk dilcisi, etnologu, folklor bilimcisi ve sözlükçüsü Mahmûd bin Hüseyin bin Muhammed ya da bilinen adıyla Kâş̧garlı Mahmûd, yaşamı süresince Türk illerini gezmiş, bu yerlerde gördüğü halkların dillerini öğrenmiş ve Türk dili ile ilgili olarak hazırlayacağı önemli eseri için gerekli bilgileri toplamıştır. Bu önemli eser, çalışmamıza da konu olan Dīvānu Lugāti't-Türk² adlı eserdir. Bu eserin büyük bir kısmı sözlükten oluşmaktadır. Kâsşgarlı, bütün Türk boylarından büyük bir özenle topladığı leksik malzemeyi bir düzen içinde sözlüğüne koymuş ve eserine aldığı kelimeleri, cümle, atasözü, beyit, dörtlük vb. şekillerde örneklendirmiş, bazen kelimeler hakkında örnek verdikten sonra, bu sözcüğün kullanımıyla ilgili Türkler arasında anlatılan bir efsaneyi veya gerçek bir olayı nakletmiştir (Çifci ve Yıldırım, 2012: 1230). Dönemin kültürel, ekonomik, sosyal, tarihî, coğrafî ve dil yapısını ortaya koyan eser üzerinde yapılan birçok çalışmaya katkı sağlamak amacıyla yaptığımız bu çalışmada Kâş̧garlı Mahmûdun, Dīvānu Lugāti't-Türk'te kaydettiği ve Eski Türkçenin söz varlığının önemli bir parçası olan kumaş terimleri belirlendikten sonra bu terimlerin tarihsel süreçteki durumları ortaya konmaya çalışılmış, yararlanılan çeşitli etimolojik sözlükler aracılı̆̆ıyla kumaş terimlerinin kökeni üzerine yapılan yorumlar aktarılmış, ödünçleme yoluyla alınan kumaş isimlerinin ödünçlendiği veya ödünçlenmiş olabileceği diller tablo halinde sunulmuştur.3 Bu bağlamda, Dīvānu Lugāti't-Türk'te yer alan agı, ay, barçın, beçkem, bıçış, böz, çaydam, çek, çekrek, çınahsı, çit, çuz, egin, eşgürti, eşük, hulı̄, içmek, içük, kaçaç, kamdu, keçe, kemek, kenzi, kerim, kez, kị̣iz kidiz, kimişge, lohtay, mındatu, şalaşu, tahçek, tanuk, tōnluk, torku, töșeklik, uyma, ületü, züngüm kelimeleri aşağıda alfabetik olarak sıralanmış ve incelenmiştir. ${ }^{4}$

\footnotetext{
2 Eser ve yazar hakkında yapılan çalışmalar (makale ve bildiri) için ayrıca bkz. Coşar, A ve Güneş B., 2011a; Coşar, A. ve Güneş B., 2011b.

3 Dankoff ve Kelly (1982-1985) Compedium of Turkic Dialects adlı DLT neşrinde mevcut kelimelerin tematik bir dizinini paylaşır. Buna göre; “Gündelik Yaşam” alt başlığında yer alan "Elbise ve Kumaşlar” bahsinde yün anlamına gelen yuך ve kars; yün artığı anlamına gelen yap, yapg்ut, yapaku vb. ifadeleri de bu kategoriye dahil eder. Ancak kelimenin bir kumaş türü saylabilmesi için işlenmiş olması gerektiğinden ve bununla beraber yatuk, samda, çigin, yurun yuḳa kelimeleri de DLT’nin farklı neşirlerinde farklı anlamlandırıldığından çalışmamıza dahil edilmemiştir.

4 İncelemede verilen terimlerin anlamları için; Ercilasun ve Akkoyunlu (2015) adlı eser temel alınmış, eserde geçen terimlerin anlamları ve örnek cümlelerin geçtiği yerler parantez içinde belirtilmiştir.
} 


\author{
1. $a g 1$ \\ “ipek kumaş” (Ercilasun ve Akkoyunlu, 2015: 57/43) \\ sewünmegil yund ügür adgır anın \\ altun kümüs bulunupan agı tawar
}

At sürüsü, aygır, kısrak ve bunlarla beraber gümüş, altın ve ipek bulunca sevinme. Yani bunlardan kendine bir iş yarat demek istiyor (Ercilasun ve Akkoyunlu, 2015: 343/277)

Kelime ilk kez bu anlamıyla runik harfli Türk yazıtlarından KT K12; BK K5; KT G7 vb. satırda geçmektedir (Aydın, 2017). Eski Uygurcada ise 'kostbarer Stoff Material (für Kleider) // değerli kumaş, (elbise için) malzeme' anlamıyla geçmektedir (Röhrborn 2015, 56-57). Clauson, bu kelimenin XI. yüzyıldan itibaren 'silk brocade // sırmalı ipek kumaş' vb. şekilde, XI. yüzyıldan önce ise 'treasure // hazine' şeklinde kullanıldığını belirtmektedir (ED 78a). Nadalyayev vd., bu kelimenin ilk anlamını 'драгоценности // mücevher, сокровища // hazineler, дары // hediyeler' olarak verirken ikinci anlamını 'шелковая ткань // ipek kumaş' şeklinde vermektedir (DTS 17b). Starostin vd., de aynı şekilde kelimenin ilk anlamını 'treasure // hazine' olarak verirken ikinci anlamını 'silk brocade // sırmalı ipek kumaş' şeklinde vermektedir (EDAL 276).

2. $a y$

“turuncu renkli ipek" (Ercilasun ve Akkoyunlu, 2015: 32/18)

Atalay, kelimenin DTS'de iy (ay?), Clauson'da 1: Dankoff-Kelly $d$ (?) şeklinde geçtiğini belirtmektedir. Nadalyayev vd, kelimeyi 'выражающее отношение несогласие // ifade ilişkisinde anlaşmazlık' şeklinde açıkladıktan sonra kelimenin kullanımının iy şeklinde mi ay şeklinde mi olduğuna şüpheli bakar (DTS 205b). Clauson ise, bu kelimeyi hapax legomenon olarak verdikten sonra kökeninin Çince olabileceğini, anlamının ise 'variegated, rainbow coloured (clothing) // rengarenk, gökkuşağı renginde (elbise)' olduğunu belirtir. XI. yüzyll Hakaniye Türkçesinde ise anlamını 'oranged-coloured brocade // turuncu renkli ipek' şeklinde verir (ED 1b).

\title{
3. barçın
}

“ipek, ipekli kumaş” (Ercilasun ve Akkoyunlu, 2015: 574). Şiir: türlüg çeçek yazıldı / barçın yadım kerildi / uçmak yeri körüldi / tumlug yana kelgüsüz. Diyor ki: Türlü çiçekler açıldı. Sanki ipek halı yayıldı. Böylece cennet yeri görüldü. Mevsim öyle ılıklaştı ki soğuk hiç dönmeyecek (Ercilasun ve Akkoyunlu, 2015: 72/58)

barçın boḍuıı ondı “ipekli kumaş vb. şeylerin rengi solup gitti” (Ercilasun ve Akkoyunlu, 2015: 97/90)

Kelime 'Brokat // sırma kumaş' şekliyle ilk kez Eski Uygurca metinlerde tanıklanmıştır (Ayazlı 2016: 69). Clauson, bu kelimenin anlamını 'silk brocade // sırmalı ipek kumaş' olarak verdikten sonra kelimenin purçın, purçin, purçum, purçun, porçăm, purçăn, porçin, purçēn şeklillerinin olduğunu da belirtir (ED 357b). Buna ek olarak bu kelime ile aynı anlama gelen kelimeleri ağı:, essgü:ti:, çi:t, çıhansı:, çikin, çuz, torku:, ka:fğar, kaçaç, kutay, hulı̀, lohtay, züngüm şeklinde sıralar (ED 357b). Nadalyayev vd., bu kelimeyi 'шелковая материя //ipekli malzeme' şeklinde vermektedir (DTS 83b). Räsänen ise kelimeyi barčun, barčyn (barçun, barçın) şeklinde verdikten sonra anlamını 'Brokat // ipek kumaş' olarak açıklar (VEWT 63a). Kelimeye Caferoğlu (1968: 33) 'bir kumaş türü, kadife' anlamını vermiştir. 


\section{eşüklük barçın}

“şal için kullanılan, uçları ipekli kumaş” (Ercilasun ve Akkoyunlu, 2015: 87/78)

\section{4. beçkem}

“ipekten veya yaban öküzü kuyruğundan yapılan ve savaşta kahramanın kim olduğunu gösteren alamet. Oğuzlar bunu berçem diye adlandırırlar” Şiir: beçkem urup atlaka / Uygurdakı Tatlaka/ogrı yawuz ıtlaka / kuşlar kipi uçtumız. Diyor ki: Atlarımıza alamet vurduk ve Uygur itlerine yöneldik -halkı kastediyor-. Kuşların uçması gibi onlara doğru uçtuk ve sonunda üzerlerine indik (Ercilasun ve Akkoyunlu, 2015: 242 /211, 243 / 211).

Clauson, kelimenin (?peçkem) / berçem (?perçem) şeklinde kullanımlarını da verdikten sonra kelimenin kökeninin Farsça olduğunu belirterek İranî dillerinden Wakhi dilinde bickam şekliyle yaşadığını belirtir. Hakaniye Türkçesinde (XI. yüzyl) beçkem şeklinde görünen kelimenin açlklamasını ise 'a badge that is a piece of silk or the tail of a wild oh that warriors wear as a badge on the day of battle // ipekten veya yaban öküzü kuyruğundan yapılan ve savaşta savaşçlların taktığı nişan, alamet' şeklinde vermiştir (ED 295a). Nadalyayev vd. kelimeyi 'бунчук из шелке или хвоста антилопы // (at veya antilop kuyruğundan yapılmış ipekler’ biçiminde açılar ve perčäm maddesine göndermede bulunur (DTS 9ob). Räsänen ise kelimeyi ‘Kriegsabzeichen aus Seide od. mit einem Antilopenschwanz / / Antilop kuyruğuyla veya pamuktan yapılan savaşta kullanılan rozet, alamet' olarak verdikten sonra kelimenin Oğuzlarda barçam şeklinde kullanıldığını da belirtmiştir (VEWT 66b). Kâş̧garl, bu kullanımın nedenini Ŏguzların Farslara yakın olması ve bu yolla Farsçadan birçok kelime almaları olarak açıklamıştır. Alıntı bir kelime olan beçkem, bugün sadece Türkiye Türkçesi ve Anadolu ağızlarında perçem biçimiyle yaşamaktadır.

\section{5. biçı̧̧}

"büyüklerin ziyafetine giden kimselere verilen kumaş parçasının adı" (Ercilasun ve Akkoyunlu, 2015: 184/157)

Clauson, XI. yüzyllda Hakaniye Türkçesinde görülen bu kelimeyi hapax legomenon olarak verdikten sonra kökenini bıç-fiiline dayandırır. Açılamasını ise 'the word for any piece of brocade given to a guest who attended banquets given by notables, and feasts // ziyafetlere katılan misafire soylular tarafindan verilen zerkeş, sırmalı ipek kumaş parçasının adı’ şeklinde verir (ED 296a).

\section{6. $b \ddot{o} z^{5}$}

"bez" (Ercilasun ve Akkoyunlu, 2015: 15/8, 36/23, 87/78 vd.)

Clauson, böz kelimesinin muhtemelen Grekçe $\beta u ́ \sigma \sigma o s$ (bussos) 'linen // keten kumaş' kelimesinden türemiş olduğunu ancak kelimenin Türklere nasıl ulaştığının belirsiz olduğunu öne sürerek kelimenin açıklamasını 'cotton cloth // pamuklu kumaş' biçiminde yapar. Türkmencede yaşadığını belirttiği sözcüğün neredeyse tüm Türk dillerinde -ö- sesini taşıdığını ancak nadir olarak bez ve biz biçimlerinin de görüldüğünü vurguladıktan sonra bu ses farklılı̆̆ının sebebini Arapça bazz ve Grekçe visso söyleyişlerine dayandırır. Kelime, günümüz Türkiye Türkçesinde de bez biçiminde yaşamaktadır (ED 389a). Nadalyayev vd., bӧz kelimesinin açıklamasını 'хлопчатобумажные ткани, холст, бязь // pamuklu kumaş, keten, patiska' biçiminde verdikten sonra bez maddesine göderme yapmıştır (DTS 118b). Räsänen, kelimeyi 'Hanfgewebe, Baumwollstoff // kenevirden yapılmış dokuma, pamuklu kumaş'

Kelime hakkında yapılan çalışmalar için bkz. Róna-Tas, 1975: 155-163; Ecsedy, 1975: 145-153; Raschmann, 2008: 121-150; Miller, 2005: 279-287; Vovin, 2018: 263-284; Karaağaç, 1998: 361-387; Rozycki, 1994; Güner, 2016: 34-41; Özyetgin, 2004: 90-105; Doerfer, 1975: 1-59. 
biçiminde açıklar. Sonrasında kelimenin Grekçeden Arapça yoluyla Türkçeye girdiğini belirterek kelimenin Kazakçada, Oyratçada, Teleütçede, Soyon Türkçesinde ve Kazan Tatarcasında kullanıldığı bildirir (VEWT 72b). Raschmann ise sözcüğün 6. yüzylldan itibaren tanıklanabildiğini öne sürer. Soğdca wšyny kelimesi ile Eski Türkçe böz kelimesi arasındaki ilişki için ve kelime etimolojisi için bkz. Raschmann, 1995: 20-25; kelimenin günümüzde kullanımı ve yaşadığı lehçeler için bkz. Sevortyan, 1978: 102.

eteklik böz

“etek yapmak için kullanılan kumaş” (Ercilasun ve Akkoyunlu, 2015: 87/178)

yamaglik böz

“yamamak için hazırlanmış kumaş vb. bir şeyin parçası” (Ercilasun ve Akkoyunlu, 2015: 466/370)

7. çaydam

"yağmurluk yapmaya ve yatak doldurmaya yarayan ince bir keçe" (Ercilasun ve Akkoyunlu, 2015: $522 / 205)$

Clauson, XI. yüzyılda Hakaniye Türkçesinde görülen bu kelimeyi çıdam biçiminde verdikten sonra anlamını 'the name of thin felt, which is used to make raincoat and to stuff mattresses // yağmurluk yapmak ve şilteleri doldurmak için kullanılan ince keçenin adı' şeklinde açıklar (ED 431b). Nadalyayev vd., kelimeyi 'тонкий войлок используемый для одеял и накидок от дождя // battaniye ve yağmurluk yapmak için kullanılan ince keçe' şeklinde açıklar (DTS 136b).

8. çek

“çizgili aba kumaş şeklinde pamuklu dokuma. Bundan örtü yapılır ve Yemekler onu giyer” (Ercilasun ve Akkoyunlu, 2015: 513/411)

Clauson, çe:g biçiminde vermiş olduğu kelimeyi hapax legomenon olarak değerlendirir ve açıklamasını 'a woven cotton fabric with a striped pattern // çizgili desenli pamuk kanaviçe bir kumaş' şeklinde yapar (ED 413a). Nadalyayev vd., bu kelimeyi 'хлопчатобумажная ткань, из которой шьют верхнюю одежд // dış giyim dikilen pamuklu dokuma' şeklinde açılar (DTS 143a). Räsänen, kelimeyi 'Baumwollgewebe, aus dem die Jimäk Obergewändermachen // Yemeklerin üst giysilerinin yapıldığı pamuklu dokuma' şeklinde açılar (VEWT 102b). Starostin ise kelimeyi '1 woven cotton fabric \& хлопковая ткань // dokuma pamuklu kumaş 2 cotton shirt \& хлопковая рубашка // pamuklu gömlek 3 woollen cloth \& шерстяная ткань // yünlü kumaş 4 a k. of upper clothes (jacket, trousers, cloak) \& вид верхней одежды (куртка, шаровары, плащ) // üst giysi (ceket, pantolon, manto)' şeklinde açıkladıktan sonra; Eski Türkçe čekrek 2 (Eski Uygurca - HIV c.); Hakaniye Türkçesi čekrek 2 (MK); Türkçe čekmen', čäpkän 4; Türkmen. čăkmen 'gown // elbise'; Orta Türkçe čekmen 4, 1 (Pav. C.)8; Özbek čakmon 4; Uygur čäkmän 4; Karaim cekmen, čekmän 3; Tatar čikmen 4; Başkurt säkmän 4; Kırgıı čekmen, čepken 3, 4; Karaçay-Balkar čepken 3, 4; Oyrat čekpen, čepken 3, 4; Tuva šekpen 3, 4; Tofalar šekpen 3. gibi kullanım örneklerini verir (EDAL 423).

\footnotetext{
$6 \quad$ Kelimenin tarihî gelişimi ve kullanımı için bkz. Karahan, 2009: 401-402. Ayrıca kelime čäk biçiminde BT VII 233, 235, K 16'da geçmekte olup kelimenin kökenin Tibetçe cheg 'Punkt // nokta' kelimesinden geldiği belirtilmiştir. Sertkaya (2009: 18) makalesinde kelimenin kökeninin Çince olduğunu kaydeder. Ayrıca bkz. čäk Choi, 1992: 193. Ayrıntılı bilgi için bkz. Usmanova, 2011: 15-23. Pavet de Courteille, Abel (1820). M. Dictionnaire Turc-Oriental. Paris
} 


\section{9. çekrek}

"kölelerin giydiği yünden yapılmış aba” (Ercilasun ve Akkoyunlu, 2015: 240/208)

Clauson, kelimenin yazımını çekrek veya çeğrek şeklinde göstermiş olup telaffuzu konusunda emin olamamıştır. XI. yüzyılda kelimenin kullanımını çekrek olarak veren Clauson, kelimenin açılklamasını 'a loose woolen gown worn by slaves // köleler tarafından giyilen gevşek bir yün elbise (aba)' şeklinde vermektedir (ED 416b). Yamada (1991: 255) kelimenin açlklamasını 'pamuktan yapılmış gömlek' biçiminde yaparken; Nadalyayev vd. ise kelimenin açılamasını 'короткая нижняя одежда // kısa alt giyim' biçiminde vermiştir (DTS 143b).

\section{0. çınahsi ${ }^{9}$}

“nakışlı çin ipeği” (Ercilasun ve Akkoyunlu, 2015: 245/213)

Clauson, kelimeyi çıhansı olarak belirttikten sonra kelimeyi hapax legomenon olarak değerlendirir. Giles'den naklen Çince zhi han si "nakışlı Çin ipeği” kelimesini muhtemel kaynak olarak verir. ${ }^{10}$ Bundan sonra ise barçın kelimesine gönderme yapar (ED 409a). Nadalyayev vd., kelimeуi “китайская узорчатая шелковая материя // desenli Çin ipek kumaşı' şeklinde açıklar ve sözcüğün Çince olabileceğini ifade eder (DTS 149a).

\section{1. çit}

“üzerine nakışlar basılmış Çin ipeği” (Ercilasun ve Akkoyunlu, 2015: 495/396)

Clauson, kelimeyi 'flowered silk' and the like; a loan-word prob. ultimately derived from Sanskrit citra 'variegated (fabric etc.)'. perhaps through some Iranian language, cf. Pe. çit, which is usually means 'chintz' (a corruption of the same word) or similar cotton fabrics // "çiçekli ipek" ve benzeri. Muhtelemen Sanskritçe citra ${ }^{11}$ 'alacalı (kumaş vs.)' kelimesinden türetilmiştir. Belki bazı İran dilleri aracıllğıyla gelen ödünçleme bir kelimedir. Farsça çit -aynı kelimenin bozulmuş biçimi olan "chintz // renkli desenli pamuklu kumaş veya benzeri pamuklu kumaşlar" anlamına gelmektedir- kelimesiyle de mukayese edilmesini öne sürer. XI. yüzyılda Hakaniye Türkçesinde kullanılagelen kelimenin izahını 'a word for Chinese silk brocade with an embroidered ornamentation // nakışlı süslemeli Çin ipeği için kullanılan bir kelime’ biçiminde yapar (ED 402a). Räsänen, Farsçadan ödünçlendiğini düşündüğü bu kelimenin anlamını 'chinesischer Brokat oder Stickerei // Çin nakışı veya zerkeşi' şeklinde verdikten sonra kelimenin diğer lehçelerde kullanımlarını da açılar (VEWT 112b).

\section{2. çuz}

"kırmızı ve siyah, altınla işlenmiş Çin kumaşı (atlas)" (Ercilasun ve Akkoyunlu, 2015: 163/142)

Clauson, kelimeyi "brocade" or the like // "sırmalı ipek” vb. kumaşlar' şeklinde açıklar. Ayrıca aynı anlama gelen birçok kelimenin olduğunu da belirterek barçın kelimesine gönderme yapar. XI. yüzyılda Hakaniye Türkçesinde kullanılagelen kelimenin izahını 'Chinese gold brocade, red and black // kırmızı ve siyah, altın(la işlenmiş) Çin ipeği’ şeklinde verir (ED 431b). Nadalyayev vd., kelimenin açıklamasını

\footnotetext{
9 Atalay dipnot, DTS, Dankoff ve Kelly, Rustemov ve Kormuşin çınahsı. Ayrıca bkz. Sertkaya, 2009: 15.

Clauson'da paylașılan Çince karakterlerin pinyinleri çalıșmamızda güncellenmiștir.

Sanskritçe citra 'bright, clear, bright-coloured // parlak, açık, renkli' anlamında kullanılmaktadır (Monier- Williams, 1899: 396b).
} 
‘китайская парча с фоном алого цвета // kırmızı nakışla işlenmiş Çin zerkeşi’ şeklinde vermiş kökenini Çince чоуцзы (chou zi, з̆iu-tsi) olarak gösterir (DTS 157b).

\section{3. egin $^{12}$}

"eni bir buçuk karış boyu dört arşın olan ve Suvarların alışverişte kullandığı bez" (Ercilasun ve Akkoyunlu, 2015: 51/37)

Clauson, kelimenin anlaminı "“a piece of cotton clothes" one and half spans one and four cubits long, bihi biyāāat Suwār in which the goods sold by Suwār (are wrapped?) // Suvarlar tarafindan satılan malların sarıldığı (paketlendiği) bir buçuk karış genişliğinde boyu dört arşın uzunluğunda pamuklu kumaş parçası' şeklinde açıllar (ED 109a). Nadalyayev vd., kelimeyi 'небольшой кусок бязи // küçük bir parça patiska13' biçiminde açıklar (DTS 166a). Kelime; Eski Türkçede egin (Eski Uygur Türkçesi); Hakaniye Türkçesinde egin (MK); Türkçede eyin, ejin 'back'; Azericede ajin 'body'; Türkmencede egin (dialekt); Orta Türkçede egin (Abuşka, Pav.C.)14, in (Pavet de Courteille) 'back'; Özbekçede egin; Karaimcede $\bar{i} n$, in; Kırgızcada ijin; Kazakçada ïjĭn; Karakalpakçada ijin; Nogaycada ijin; Sarı Uygurcada igen; Hakasçada ipnř̈, Oyratçada ijin; Tuvacada eyin; Çuvaşçada avın, an; Yakutçada ien biçiminde yaşamaktadır (EDAL 495).

\section{4. eşgürtti ${ }^{15}$}

"ipek cinsinden, işlemeli bir Çin kumaşı" (Ercilasun ve Akkoyunlu, 2015: 84/75)

Kelime, ipekli kumaş anlamıyla runik harfli Türk yazıtlarından BK K3; KT G5; BK K11'de eşgiti, işgiti şekliyle geçmektedir (Aydın, 2017). Aynı zamanda kelime Eski Uygurcada işgirti biçimiyle 'ipekli kumaş' anlamıla Tekin, 1980: 49b (165,15) ve Zieme, 1985: 213b'de (12.89)'da geçmiştir. Clauson, kelimeyi éşgü:ti: biçiminde verdikten sonra açıllamasını 'a kind of Chinese embroidered silk brocade // Çin'e özgü bir tür işlemeli sırmalı ipek kumaş’ şeklinde yapar. Kelimenin Köktürkçede - $g$ - ile tespit edildiğini, Eski Uygur metinlerinde éşgirti biçiminin yaygın olduğunu belirterek aynı anlama gelen barçın kelimesine gönderme yapar ${ }^{16}$. XI. yüzyllda Hakaniye Türkçesinde ise kullanılan kelimeyi éşgü:ti: biçiminde (el yazmalarında éş̧ürti:) verdikten sonra açıklamasını 'embroidered Chinese silk brocade // işlemeli sırmalı bir Çin ipek kumaşı’ olarak yapar (ED 261a).

15. eşük $k^{17}$

"han ve beyleri yüceltmek maksadıyla mezarlarına serilsin diye gönderilen, artanı fakirlere dağıtılan kumaş" (Ercilasun ve Akkoyunlu, 2015: 48/34)

Kelime, Eski Uygurcada ‘Überdecke // yatak örtüsü’ anlamıyla geçmektedir (Tekin 1980: 27, 12.5). Clauson, kelimenin kökenini eşü:- fiiliyle bağdaştırır ve açıklamasını 'blanket, covering // battaniye,

Kelimenin tarihî gelişimi ve kullanımı için ayrıca bkz. Karahan, 2009: 423-424.

patiska pamuk ipliğiyle sık ve düzgün dokunmus,, iyi nitelikli bez.

Atalay, Besim (1970). Abuşka lûgatı veya Çağatay sözlüğü. Ayylldı Matbaası; Vámbéry, Ármin (1862). Abuska: Csagatajtörök szógyüjtemény. Emich Gusztáv M. Akad. Nyomdász Betüivel; Pavet de Courteille, Abel (1820). M. Dictionnaire Turc-Oriental. Paris.

15 Atalay, DTS, Rustemov ve Kormuşin eşkürti, Dankoff ve Kelly eşgü:ti. DLT’de fa'lu:li: babı altında olduğu için eşgü:ti: beklendiği halde eşgürti: yazıldığını kaydeder. Çincedeki özgün biçimi ne olursa olsun eski Uygur metinlerinde ve DLT'de kelime $r$ iledir. Sertkaya (2009: 19) makalesinde kelimenin kökeninin Çince olduğunu kaydeder.

Tekin (2006: 104) DLT'de geçen bu sözcü̆ün BK K 11'de geçen eşgirti “işlemeli ipek kumaş” kelimesiyle bir ve aynı olduğunu ifade eder.

eşük kelimesinin etimolojisi için bkz. Erdal, 1991: (I) 232-233; kelime hakkında ayrıntılı bilgi için ayrıca bkz. Ölmez, 2008: $333-340$. 
örtü’ biçimide yapar ve güneybatı dil gruplarında (Türkmen) eşik şeklinde yaşadığını belirtir. XI. yüzyıl Hakaniye Türkçesinde eşük biçiminde kullanılagelen bu kelimeyi 'the word for anything of brocade which is sent to be laid on graves of amirsand kings as a sign of respect, and is then later divided among the poor // hanlara ve emirlere saygı göstermek maksadıyla mezarlarına serilsin diye gönderilen, artanı fakirlere ayrılan kumaş için kullanılan kelime' olarak açıklamıştır (ED 260a). Nadalyayev vd., kelimenin ilk anlamını 'покрывало // örtü, peçe', ikinci anlamını ‘пелена, световые блики // örtü, ışık parlaması, üçüncü anlamını ise 'саван // kefen' şeklinde vermiştir (DTS 186a). Räsänen, kelimenin açıklamasını 'Kleid, Stoff als Decke für das Grab einer Standesperson, der nach her an die Armen verteilt wird // devlet adamlarının mezarına serilmek amacıyla kullanılan ve artanı fakirlere dağıtılan elbise, battaniye kumaşı' olarak açıklamıştır (VEWT 51b).

\section{6. huling}

"değişik renklerde olan ve Çinden getirilen bir ipek" (Ercilasun ve Akkoyunlu, 2015: 606/498)

Clauson, XI. yüzyllda Hakaniye Türkçesinde görülen bu kelimeyi hapax legomenon olarak verdikten sonra kökenini Çinceye dayandırır ve barçın kelimesine atıf yapar. Kelimenin açılklamasını ise 'a word for silk of variegated colours imported from China // değişik renklerde olan ve Çinden ithal edilen bir ipek türü için kullanılan kelime' şeklinde verir (ED 622b).

\section{7. $\mathrm{kaçaç}^{18}$}

"bir Çin ipeklisi" (Ercilasun ve Akkoyunlu, 2015: 408/319)

Clauson, kelimeyi 'one of several words for silk fabrics // ipek kumaşlar için kullanılan birkaç kelimeden biri' şeklinde açıklar ve barçın kelimesiyle mukayese eder (ED 59ob). Nadalyayev vd., kelimeyi 'copt китайской шелковой материи // Çin ipekli kumaş türü’ olarak açıklamıştır (DTS 40ob). Starostin ise kelimeyi 'Chinese brocade, woven fabric // Çin ipeklisi, dokuma kumaş (китайская парча, узорная ткань //Çin brokarı, desenli kumaş)' şeklinde verir (EDAL 627).

\section{8. kamdu}

“dört arşın uzunluğunda, bir karış genişliğinde kumaş parçası. Üzerine Uygur hanının mührü basılır ve alışverişler onunla yapılır. Eskiyip yıprandığı zaman yedi yılda bir yamalanır, yıkanır ve üzerine mühür tekrar basılır" (Ercilasun ve Akkoyunlu, 2015: 211/181)

Maralbek ve Koçak (2018: 189) kamdu sözcüğünün yaklaşık uzunluğu 3 metre, eni 20 cm olan kumaşa denk geldiğinden bahsettikten sonra onun 10. ve 12. yy'da Türk yurdunda kâğıt paranın ilk nüshası olan "kumaş para" niteliğinde kullanıldığını ifade eder. Bu niteliğe sahip olan kamdınun -özel olarakkumaştan yapıldı ̆̆ını ve belli bir değer seviyesi olduğu da ekler. Kelimeyi oluşum şekli bakımından inceleyen Abik (2009: 273) ise Dīvānu Lugāti't-Türk'te görülen, sonu - $d l$ veya $-d U$, -tl veya - $t U$ ile biten isimleri üç bölüme ayırdıktan sonra birinci bölümü, -n- çatı eki üzerine gelen -n-dґlar ve tek kelimede $d U$ ikinci bölümü, fiil kökü üzerine gelen $-d U$ lar ve $-t U$ lar veya $-d l$ oluştururken ücüncü bölümü ise açıcça bir fiil veya isim kökü ile bağlantısı görülmeyenlerin oluşturduğunu belirtir ve kamdu kelimesini üçüncü bölüme dahil eder. Alışverişte para karşılığında ödeme aracı olarak kullanılan bu kelimeyi Clauson, hapax legomenon olarak verdikten sonra kökeninin Çince gan (MC kam) ve $d u$ (MC $d u$ ) veya bunlara benzer bir kelimeden oluştuğunu belirtir. Kelime XI. yüzyılda Hakaniye Türkçesinde 'a piece of linen four cubits one span in dimension, sealed with the seal of the Uighur hān and used in commercial

18 Sertkaya (2009: 20) makalesinde kelimenin kökeninin Çince olduğunu kaydeder. 
transactions; when it becomes worn and tattered, it is patched up every seven years, washed and resealed // Uygur hanının mührüyle mühürlenen ve ticarette kullanılan dört arşın uzunluğunda bir karış genişliğinde keten kumaş parçası. Yıpranıp yırtıldığı zaman yedi yılda bir onarılır, yıkanır ve yeniden mühürlenir' şeklinde vermiştir (ED 626b). Nadalyayev vd., kelimeyi 'куски материи с печатью уйгурского хана, имевшие хождение в качестве денег: раз в семь лет чинились, стирались и на них снова ставилась печать // Para olarak kullanılan, Uygur Han'ın mührüyle mühürlenen kumaş parçaları: Yedi yılda bir tamir edilir, yıkanır ve tekrar mühürlenir' biçiminde açıklamıştır (DTS 415a). Zieme (1976: 247) ise kamdu kelimesini kuanpo ile ilişkilendirerek, iki kelime arasındaki ilişkinin yanlış yazımdan kaynaklanabileceğini, Arap yazısındaki imlâda kuanponun imlâsının kamdu şeklinde yazılmış olabileceğini belirtmektedir.

\section{9. keçe}

“Oğuzcada keçe” (Ercilasun ve Akkoyunlu, 2015: 541/442)

Kâsgarlı nın eserinde verdiği bilgiye göre yaygı, yere serilen kilim anlamında Karahanlı sahası Türkleri kiziz (kiḍiz kidiz) kelimesini tercih ederken Oğuzlar'ın (Türkmenlerin) daha XI. yüzyllda bugün olduğu gibi keçe kelimesini kullandıkları görülmektedir (Genç, 1998: 14). Oğuzların kullanmayı tercih ettikleri bu kelimeyi Clauson, 'felt // keçe' olarak açıkladıklatan sonra özellikle Oğuz grubunun güneybatı dil gruplarından Azeri, Osmanlıca, Türkmencede keçe olarak kullanıldığını söyler ve sonra kidiziz kelimesine gönderme yapar. Oğuzcada XI. yüzyılda keçe, Çağataycada XV. yüzyllda kęçe, Türkmencede keçe (Kıpçakça kiyiz), Osmanlıca kęçe şeklinde kullanıldığını belirtir (ED 694b). Nadalyayev vd., kelimeyi 'войлок, кошма // keçe' biçiminde açıklamıştır (DTS 291b). Räsänen, kelimenin kullanımını Çağatayca ve Osmanlıcada käcä olarak verdikten sonra açıklamasını 'Filz, Filzdecke, Filzteppich // keçe, keçe battaniye, keçe halı; Çağatayca, Osmanlıca, Azericede kiče, Türkmencede keče 'войлок // keçe', Çuvaşcada kəśse 'Filz // keçe' biçiminde yapar (VEWT 245b).

\section{0. kemek}

“pamuktan yapılan, nakışlı ve şeritli bir kumaş. Aba yapılır. Kıpçaklar onu yağmurluk olarak kullanırlar" (Ercilasun ve Akkoyunlu, 2015: 197/169)

Clauson, kelimeyi hapax legomenon olarak verdikten sonra kelimenin ön ek, ödünç kelime olabileceğini düşünür. Daha sonra bu kelimeyi 'like many other names of fabrics, a loan word.; the word has one fatha which might be over either of the first two consonants. Hak. XI kemek: a woven cotton material, embroidered, with white stripes', used to make outer garments; the Kipçak make raincoats from it // diğer birçok kumaş isimleri gibi, alıntı kelime; kelimenin ilk iki ünsüzden birinin üzerinde olabilecek bir fetha ${ }^{19}$ vardır. XI. yüzyıl Hakaniye Türkçesinde kemek dış giyim yapmak için kullanılan pamuk kanaviçe, nakışlı ve şeritli bir kumaştır; Kıpçaklar ondan yağmurluk yaparlar' biçiminde açıklamıştır (ED 722b). Nadalyayev vd., kelimeyi kemäk biçiminde verdikten sonra açıklamasını 'ткань в полоску, из которой делают накидки и плащи // pelerinlerin (aba) ve yağmurlukların yapıldığı çizgili kumaş' biçiminde yapmaktadır (DTS 297b). Starostin, kelimenin açıklamasını 'a.k of of striped cloth for making upper clothes // üst giysi yapmak için kullanılan çizgili kumaş (вид полосатой ткани для изготовления верхней одежды // dış giyim yapmak için kullanılan çizgili kumaş türü): Karakh. kemek // Hakaniye Türkçesinde kemek' biçiminde yapmıştır. Bunun yanısıra kelime için; 'The isolated OT word may be borrowed from Eastern Iranian: cf. Pers. kamha < Chin. gimhua (see VEWT 229 on further loans: Pers. >

19 fetha (Türkçede üstün olarak bilinir) işareti harfin üzerine çizilen hafif eğik düz bir çizgidir. =. Bulunduğu harfi e ila a arasındaki bir sesle okutur. İnce harfler e sesine, kalın harfler ise a sesine yakın bir sesle seslendirilir. 
Turkic qamqa > Russ. камка 'striped silk cloth'). Cf. other similar cases (like Sak. kamaiška > MK kemišge etc.) // Belki Doğu İran dillerinden Farsça kamha < Çince gimhua kelimesinden alınan ve izole edilen Eski Türkçe kelimesidir (Ayrıntılı bilgi için bkz. VEWT $229^{20}$ ve daha fazla ödünçleme için: Farsça > Türkçe qamqa > Rusça камка 'striped silk cloth // çizgili ipek kumaş' (benzerleri için ise Khotan-Saka kamaiška > MK kemišge vb. kelimelerine bakılabilir’ açıllamasını yapar (EDAL 640).

\section{1. kenzi}

“değişik renklerde; kırmızı, sarı, yeşil ${ }^{21}$ Çin kumaşı” (Ercilasun ve Akkoyunlu, 2015: 213/183)

Clauson, kelimeyi hapax legomenon olarak verdikten sonra kökeninin Çince olduğunu, Prof. Simon'un kelimenin orjinalinin juan zi olduğunu ve Giles'in Çince sözlüğünde bu kelimenin MC'de kị wen-tsi 'thin silk' and more specifically 'a silk handkerchief' // Orta Çince'de kị wen-tsi yani 'ince ipek' ve daha spesifik olarak 'ipek mendil' biçiminde geçtiğini belirtir. IX. yüzyllda Hakaniye Türkçesinde kelimenin açılamasını ise 'a Chinese woven fabric of mixed colours red, yellow and green // kırmızı, sarı ve yeşil karışık renklerde Çin'e özgü bir dokuma kumaşı’ biçiminde yapar (ED 735a). Nadalyayev vd., kelimeyi 'цветная ткань китайского производства // renkli Çin kumaşı' biçiminde açılar ve kelimenin kökeninin Çince olması ihtimali üzerinde durur (DTS 298b).

\section{2. kerim}

“nakışlı kumaş” (Ercilasun ve Akkoyunlu, 2015: 201/171)

Türkler, XI. yüzyılda evlerinin duvarlarını kırmızı renkli aşu toprağı ile süslüyorlar, bu süslere bezek, süsleme işine de bezemek diyorlardı. Ancak, aşu toprağı ile yapılan süslemeden başka, duvarlara nakışlı çarşaf, keçe veya halı gibi şeyler asmak veya germek suretiyle de evlerinin duvarlarını süslediklerini görüyoruz. Bu tür duvar örtülerine onlar kerim veya XI. yüzyll Türkçesinde "duvar" demek olan tam (dam) kelimesinden alarak tam kerimi "duvar örtüsü" diyorlardı (Genç, 1998: 16). Bu bilgiden yola çıkarak Türklerde duvara halı asma veya duvar süsleme geleneğinin köklerinin XI. yüzyıla kadar uzandığını rahatlıkla ifade edebilmekteyiz. Duvar halısı veya örtüsü anlamına gelecek şekilde kullanılan bu kelimeyi Clauson, hapax legomenon olarak verdikten sonra kelimenin ker- fiilinden türediğini belirtir ve 'a single act of spreading out // tek bir yayılma hareketi' ifadesini ekler ve yadım kelimesine gönderme yapar. XI. yüzyılda Hakaniye Türkçesinde kerim biçiminde kullanılan kelimenin açıklamasını ise 'an embriodered curtain // nakışlı perde’ biçiminde yapar (ED 745b). Nadalyayev vd., kelimeуі 'ковер, сюзане // halı, suzani22' biçiminde açılklamıştır (DTS 301a).

\section{3. $\mathrm{kez}$}

"bir tür Çin kumaşının adı" (Ercilasun ve Akkoyunlu, 2015: 164/142)

Clauson, kelimeyi hapax legomenon olarak verdikten sonra kelimenin Farsça kaz/ kaj/ kaç'raw silk // ham ipek' kelimesinden alınmış olabileceği üzerinde durur ve barçın kelimesine gönderme yapar. XI. yüzyılda

\footnotetext{
20 krş. VEWT 229b kamka 'ein dem Atlas ähnlicher Seidenstoff // ipekli kumaş benzeri bir atlas'

21 Eski Türk kültüründe renk kavramı, geçmişten günümüze kadar yaşanan gelişmelere bağlı olarak değişikliğe uğramıştır. Devlet olmanın göstergelerinden biri sayllan bayraklarda kullanılan renkler, sosyal hayatta kullanılan renkler, giyimkuşam ve kullanılan eşyalardaki renkler daima belirli anlamları ifade edecek şekilde seçilmiş ve bu seçim nesilden nesile aktarılarak günümüze kadar ulaşmıştır. Eski Türk kültüründe kullanılan renklerin seçimi ve ifade ettikleri anlamlar hakkında ayrıntılı bilgi için bkz. Küçük, 2010.

22 Farsça kökenli süzeni, sûzenî sözcüğünün ilk anlamı 'iğneyle ilgili', ikinci anlamı ise 'kasnak iğnesiyle işlenen ince bir nakış çeşidi' olarak verilmektedir (Ayverdi ve Topaloğu, 2011: 2928a).
} 
Hakaniye Türkçesinde kullanılagelen kelimenin açıklamasını da 'the name of Chinese brocade // Çin ipek kumaşının adı' biçiminde yapar (ED 756a). Kelime, Steingass'ta kez $j$ <kez> biçimiyle aynı anlamıyla tanıklanmıştır (Steingass, 1892: 1027a).

\section{4. kidiz kidiz}

"keçe"

ol kidizni esriledi “o, keçeyi, dövmeler yaparak kaplan derisi gibi nakışladı" (Ercilasun ve Akkoyunlu, 2015: 184/157)

kız anasıja kị̣iz sırışı "kız annesine şuvalama dikişiyle keçe dikmede çok yardım etti (Ercilasun ve Akkoyunlu, 2015: 317/259)

ol kīzka kị̣iz sırıttı “O; keçeyi kıza sıkıca ve büktürerek teyellettirdi” (Ercilasun ve Akkoyunlu, 2015: 417/328) vd.

Kâsgarı Mahmûd, eserinde geçen kiwiz kelimesini "yaygı; yani halı ve kilim gibi şeyler" olarak tarif ettikten sonra küvüzü de "yaygı; yünden dokunmuş döşek, halı, kilim ve yaygı gibi şeyler" olarak açıllamaktadır. Görülmektedir ki XI. yüzyıl Türkçesinde yazım kelimesinden başka kwiz veya küvüz kelimesinin de "yaygı" cins ismi olarak kullanıldığı, ama bu sonuncuların daha çok keçe, döşek ve sair yaygı türlerini ifade ettiği anlaşılmaktadır (Genç, 1998: 14). Türklerin evlerine yaydıkları halı, kilim anlamına gelen bu kelime, keçe anlamıyla ilk kez runik harfli Türkçe metinlerden BK D1'de aynı anlamıyla tanıklanmıştır (Aydın, 2017). Ayrıca Eski Uygurcada da 'Filzdecke // keçe örtü' anlamıyla geçer (Tekin, 1980: 65, 73.24). Clauson, kelimenin anlamını 'felt //keçe' olarak verdikten sonra güneybatı dil grupları haricinde günümüzdeki tüm modern dillerde yaşadığını belirtir ve güneybatı dil gruplarında keçe kelimesinin kullanıldığını vurgular (ED 707a). Nadalyayev vd, kelimeуi ‘палас, кошма // kilim, büyük keçeli paspas' biçiminde açılamış ve örneklendirmiştir (DTS 306b). Räsänen, kelimenin kullanımını kidiz, ki'iz olarak verdikten sonra açılamasını 'Filz //keçe' biçiminde yapar. (VEWT 270a). Ayrıca Starostin’in de sözlüğünde yer alan kidiz kelimesinin tarihî ve çağdaş Türk lehçelerindeki biçimleri için bkz. (EDAL 846).

\section{kedüklük kiḍiz}

"yağmurluk yapmak için hazırlanmış keçe" (Ercilasun ve Akkoyunlu, 2015: 254/223)

kidizlik yū̄

"keçe yapmak için hazırlanan yün" (Ercilasun ve Akkoyunlu, 2015: 253/222)

\section{5. kimişge}

“nakışlı Kaşgar keçesi” (Ercilasun ve Akkoyunlu, 2015: 246/214)

XI. yüzyılda halı ya da duvar örtüsü yapılan yaygılar için kullanılan düz desenli keçelerin varlığının yanısıra nakışlı keçelerin de bulunduğunu kimişge kelimesinden anlıyoruz. Clauson, kelimeyi hapax legomenon olarak verdikten sonra kelimenin 'something laid down on the ground // yere serilmiş bir şey' anlamına gelen kemiş- fiilinden türediğini belirtir. XI. yüzyılda Hakaniye Türkçesinde kemişge biçiminde kullanılan kelimenin açıklamasını 'an embroidered Kāşğar felt (rug?) // nakışlı bir Kaşgar keçesi (kilimi?)’ biçiminde yapar (ED 724b). Nadalyayev vd. ise kelimeyi kımıškä (kimişke) olarak verdikten sonra açıklamasını ‘палас с узорами кашгарского производства // Kaşgar motifiyle üretilen bir kilim' biçiminde yapar (DTS 307b). 


\section{6. lohtay}

“üzerinde sarı pullar olan kırmızı Çin ipeklisi” (Ercilasun ve Akkoyunlu, 2015: 550/451)

Clauson, kelimeyi hapax legomenon olarak verdikten sonra kelimenin kökeninin Çince olduğunu belirtir. Buna ek olarak Brockelmann'ın alanın uzmanı B. Schindler'e dayanarak, kelimenin yapısının 10 'raw silk // ham ipek' ve tai 'girdle // kuşak' kelimelerinin bir araya gelmesiyle oluştuğunu söylediğini ekler ve barçın kelimesine gönderme yapar. Kelimenin XI. yüzyllda Hakaniye Türkçesinde 'red Chinese brocade with small gold coins (or spangles) attached // üzerinde altın madenler (veya pullar) olan kırmızı Çin zerkeşi’ anlama gelecek şekilde kullanıldığını belirtir (ED 763b). Nadalyayev vd., kelimenin kökenin Çince olabileceği üzerinde durduktan sonra kelimeyi 'китайский материал красного цвета с золотыми чешуйками // altın pullu kırmızı Çin kumaşı biçiminde açıklar (DTS 334a). Räsänen, kelimenin açıklamasını 'roter chinesischer Brokat mit gelben Münzen besetzt // sarı paralarla süslenmiş kırmızı Çin zerkeşi’ biçiminde yapar (VEWT 318a).

\section{7. mindatu ${ }^{23}$}

“ipek (ipekli kumaş)” (Ercilasun ve Akkoyunlu, 2015: 246/215)

Clauson, kelimeyi hapax legomenon olarak verdikten sonra kelimenin mandirr:, mundaru: ve sanduwa:ç kelimeleri altında indekslendiğini belirtir ve sanduwa:ç kelimesinin bu anlama gelmesinin düşündürücü olduğunu söyler. Clauson’a göre kelime Sanskritçe mandita kelimesiyle ilgili olabilir. Sanskritçe mandita 'adorned, decorated // bezenmiş, süslenmiş' anlamına gelmektedir (Monier-Williams, 1899: 775c). Zieme (1997: 151) ise kelimenin Moğolcada mindasu(n) 'floss-silk // ham ipek' ve Kalmukça mindas"n n 'wad'24 ilişkili olduğunu belirtmiştir. Boberg (1954-1955: 474) de kelimeyi Moğolcada mindusu biçiminde göstermiş ve anlamını 'silk wadding // ipek duvak' biçiminde vermiştir. Kelime XI. yüzyılda Hakaniye Türkçesinde mındatur Çiğilcede mandırı 'the word for gathering which assembles in the presence of the bride-groom an bride at night when ceremonial gifts are presented // gelin ve damada onların da hazır bulunduğu sırada gece hediyelerini vermek üzere bir araya gelmeyi ifade eden toplanma kelimesi' anlamıyla kullanılmaktadır. Ayrıca kelimenin Hakaniye Türkçesinde kullanılan mundaru şeklini de vermiş olup kelimenin açıklamasını 'a bridal canopy 25 of silk // ipekten yapılmış bir düğün gölgeliği' olarak yapmıştır (ED 768a).

\section{8. şalaşu}

"bir tür Çin dokuması" (Ercilasun ve Akkoyunlu, 2015: 224/193)

Clauson, kelimeyi hapax legomenon olarak verdikten sonra kelimenin kökeninin Çince olabileceğinden bahseder. Kelimenin XI. yüzyılda Hakaniye Türkçesinde taşıdığı anlamı 'a kind of Chinese woven fabric // bir çeşit Çin dokuma kumaşı' biçiminde verir (ED 868a). Nadalyayev vd., kelimenin açıklamasını ‘вид китайской материи // Çin kumaş türü’ biçiminde yapmıştır (DTS 520a). Räsänen, kelimenin açıklamasını 'eine Art chinesischen Gewebes // bir çeşit Çin kumaşı' biçiminde vermiştir (VEWT 441b).

Atalay, Rustemov ve Kormuşin mindetü, Clauson, Dankoff ve Kelly mındatu.

wad kelimesi için bkz. Ramstedt, 1935: 263a.

bridal canopy have the same meaning that wedding canopy under which a bride and groom stand during the marriage ceremony // Evlilik merasimi sırasında gelinle damadın birlikte altında durdukları gölgelik. 


\section{9. tahçek $^{26}$}

"bir tür Çin ipeği” (Ercilasun ve Akkoyunlu, 2015: 240/208)

Clauson, kelimeyi hapax legomenon olarak verdikten sonra kelimede geçen $/ h /$ sesinin $/ h /$ sesinin yanlış yazımı olabileceğinden bahseder ve benzer anlam taşıyan tahtu ${ }^{27}$ kelimesine gönderme yapar. Sonrasında kelimenin kökeni için tanımlanamayan bir dilden alıntılanmış olabileceğini ancak $/ h /$ sesi nedeniyle Çinceden alınması muhtemel bir kelime olmadığını da ekler. Kelimenin XI. yüzyılda Hakaniye Türkçesinde taşıdığı anlamı ise 'a kind of Chinese silk // bir çeşit Çin ipeği' olarak verir (ED 467b). Nadalyayev vd., kelimeyi tah̆ček (tahçek) biçiminde verdikten sonra açıklamasını 'сорт китайского шелка // bir tür Çin ipeği’ biçiminde vermiştir (DTS 527b).

\section{0. tanuk}

“çevgen ${ }^{28}$ vuruşunda topu kaleden (mine1-maqbai) geçirene verilen ipekli kumaş parçası; savaşta kısa mızrakların ve bayrakların ucuna iliştirilen ipek kumaş" (Ercilasun ve Ảkkoyunlu, 2015: $604 / 496)$

Clauson, kelimenin ilk anlamını 'hediye' olarak açıkladıktan sonra ikinci ve üçüncü anlamlarında kelimenin kumaş olarak kullanımını verir. Kelimenin ikinci anlamı için; 'the word for any piece of brocade which is given to a man given strikes the ball through the goal at polo // polo oyununda gol atana verilen ipek kumaş parçasına verilen ad' açıklamasını yaparkan ikinci anlamını ise 'the piece of silk which are fastened to the heads of lances and standards in war time // savaş zamanında mızrakların ve sancakların tepesine bağlanan ipek parçası' biçiminde vermiştir (ED 519a). Nadalyayev vd., de kelimenin ilk anlamını 'hediye' olarak verdikten sonra ikinci ve üçüncü anlamlarında kelimenin kumaş olarak kullanılan anlamını verir. Kelimenin ikinci anlamı için 'отрез шелковой материи, вручаемый победителю на состязаниях // yarışmalarda kazanana verilen ipek kumaş parçası' açıklamasını yaparkan ikinci anlamını ise 'полотнище знамени // sancă̆a (bayrağa) takılan kumaş' biçiminde vermiştir (DTS 533a). Räsänen de kelimenin ilk anlamını 'hediye' olarak verdikten sonra ikinci anlamı için 'ein Stück Brokat als Geschenk für den Polospieler // polo oyununda kazanana verilen bir parça brokar' ikinci anlamını ise 'seidene Wimpel an der Fahne // bayrağa takılan ipeksi flama' biçiminde açıklar (VEWT 462a).

\section{1. tōnluk}

"elbise için planlanan kumaş"

ol anı̣ tōnlukın kısdı "O, elbise için planlanan kumaştan kıstı" Herhangi bir şey planlanan miktarından kısılırsa aynıdır (Ercilasun ve Akkoyunlu, 2015: 269/236)

\footnotetext{
26 Ayrıca bkz. tahčäk Choi, 1992: 195.

27 “eğirilmeden önceki ham ipek” (Ercilasun ve Akkoyunlu, 2015: 210/180). Kelimenin oluşum şekli hakkında ayrıntılı bilgi için bkz. kamdu maddesi Abik (2009: 273). Clauson, kelimeyi hapax legomenon olarak verir ve tahçek kelimesine gönderme yapar (ED 467b). Ayrica bkz. tahto Choi, 1992: 195 .

28 Halk arasında çevgen şeklinde söylenen Farsça çevgân (çûgân) kelimesinin aslı Pehlevîce (Orta Farsça) çûbikân (çûygân, çûlgân/çavlagân) (sopa, değnek) ismi olup bu kelime Arapça'ya savlecân, Türkçe'ye çöğen ve Grekçe'ye tsükanion şekillerinde girmiştir. Batılılar çevgânı ilk defa Grekler aracılığıyla Perslerden öğrenmişlerse de oyunun bütün dünyada tanınması, XIX. yüzyılda İngilizler'in Afganistan ve Kuzey Hindistan’ı işgalleri sırasında bu oyunu polo (Tibetçe bolo/pulu "top") adı altında oynamaya başlamalarından sonradır (Halıcı, 1993: 294). Oyun hakkında ayrıntılı bilgi için bkz Alan, 2019: 90-92.
} 
Nadalyayev vd., kelimeyi tonlur biçiminde verdikten sonra açıklamasını 'предназначенный для платья, одежды // elbiselik, giysi için tasarlanmış (kumaş)’ biçiminde yapmıştır (DTS 574b).

\section{2. tork $^{29}$}

“ipek"

Atasözü: Tawgaç hānnı̇ torkusı telim tenlemegip bıçmas Anlamı: "Çin hakanının ipeği çoktur. Buna rağmen ölçmeden elbiselik kesmez” Bu söz, israfı önlemek ve bir işi bilerek yapmak için kullanılır (Ercilasun ve Akkoyunlu, 2015: 215/185)

torku yonşdı "ipek vb.leri üzerinde yollar (çizgiler) belirdi” Bu, yıpranmaya yüz tuttuğu zaman olur (Ercilasun ve Akkoyunlu, 2015: 475/380) vd.

Kelime Eski Uygurcada torku biçimiyle 'Seide // ipek' anlamıyla muhtelif metinlerde tanıklanmıştır (Tekin, 1980: 125, 95.3). Clauson, kelimenin açıklamasını 'silk fabric //ipek kumaş' biçiminde verdikten sonra Moğolca, Farsça ya da ya başka bir dilden alıntılanmış olabileceğini söyler. Moğolca sözlüklere göz attığımızda ise Lessing (1960: 826a) kelimeyi Moğolcada torġa(n) biçiminde göstermiş ve anlamını 'silk // ipek', Boberg (1954-1955: 474) de kelimeyi Moğolcada torghon biçiminde göstermiş ve anlamını Lessingle aynı şekilde 'silk // ipek' olarak vermiştir. Doerfer ise torğū biçiminde gösterdiği sözcüğün Türkçeden Moğolcaya geçtiğini Moğolcadan da Türkçeye geri ödünçlenme yoluyla alındığını ifade etmiştir. Aynı zamanda çağdaş Türk lehçelerinde ve Batı dillerindeki şekilleri için bkz. Doerfer, 1965: 478-480, 884; VEWT 490a. Nadalyayev vd., kelimenin açıklamasını 'шелк // ipek' biçiminde yapmıştır (DTS 578a).

\section{3. töşeklik}

"yatak vb. şeyleri yapmak için hazırlanan ipek" (Ercilasun ve Akkoyunlu, 2015: 254/223)

\section{4. uyma}

"Türkmenlerin ayakkabı yapımında kullandıkları keçe"

ol maga uyma basışı "O, Türkmenlerin ayakkabı yapımında kullandıkları keçeyi yapmada bana yardım etti” (Ercilasun ve Akkoyunlu, 2015: 319/261)

ol maja uyma talkışdı "O, bana, kendisinden ayakkabı yapılan keçeyi bükmede yardım etti” Herhangi bir şey bükülüp fitil gibi burulursa yine aynıdır (Ercilasun ve Akkoyunlu, 2015: 370/292)

Clauson, kelimenin kökünü $u$ - olarak verir ve kelimenin anlamını 'felt boots // keçe çizme' biçiminde açıklar. Kelimeyi, modern Kuzey-Merkez dil grubu kelimesi uyuk 'keçe çizme, yünlü çorap' ve muhtemelen uyukluğ ile açıkça bağlar. Bu nedenle bu fiilin sesli harfini $u$ - olarak düzeltir. ${ }^{\circ}$ Kelimenin XI. yüzyılda Hakaniye Türkçesinde taşıdığı anlamı ise 'the (Türkmen) felt out of which boots are made // keçeden yapılan Türkmen çizmeleri’ olarak verir (ED 273b). Nadalyayev vd., kelimenin açıklamasını 'войлок, из которого делают обувь // ayakkabıların yapıldı̆̆ı keçe' biçiminde yapar (DTS 607b). Kelime, Räsänen'de ujma (uyma) şeklinde geçmesine rağmen keçe anlamına gelecek şekilde kullanılmamıştır. Ayrıntılı bilgi için bkz. VEWT 511b. Starostin, kelimeyi ojma biçiminde vermiş olup

\footnotetext{
29 torku kelimesi Kutadgu Bilig adlı eserde de geçmektedir. Baharın tasvir edildiği bölümde metne dahil olan kelime; yağız yer, yaşıl torku (ipek) yüze badı "yağız yer, yaşıl torku (ipek) yüze badı”, yani "yağız yer, yüzüne yeşil ipek tül bağladı" (Arat, 1985: 17) cümlesinde hayat bulmaktadır. Tarafımızca, metinde geçen yeryüzünün yeşil ipek tül bağlaması olayı kadınların yüzlerine yeşil ipekten tül bağlayıp yeşile bürünmelerine yahut kurumuş, çoraklaşmış olan toprağın baharda tekrardan canlanarak tüm güzelliğiyle yeşile bürünmesine benzetilmiştir.

30 Atalay oyma, DTS, Clauson, Dankoff ve Kelly uyma. krş. Kar.-Mal. uyuk "keçeden çorap şeklinde çizme” (KMTS), Kazak uyık I "yün çorap" (KTS), Kazan-Tatar oyık “çorap” (KTTS).
} 
anlamını ' 1 felt out of which boots are made // keçeden yapılan çizme, 2 leather or skin bag // deri veya deri çanta (1 войлок для сапог // çizme уapımında kullanılan keçe, 2 кожаный мешок // deri çanta)' olarak açıkladıktan sonra kelimenin Hakaniye Türkçesinde (MK) ojma biçiminde kullanıldı̆̆ını da ekler (EDAL 1166).

35. ületiü ${ }^{31}$

"erkeklerin, burunlarını temizlemek için koyunlarında bulundurdukları ipek parçası, mendil" (Ercilasun ve Akkoyunlu, 2015: 80/69)

Clauson, kelimenin ület fiilinden türemiş olabileceği ihtimali üzerinde durduktan sonra kelimenin açıklamasını 'silk handkerchief // ipek mendil' olarak verir. Kelime, din dışı Eski Uygurca metinlerde ületü 'bez, mendil' anlamıyla tanıklanmıştır (Ayazlı, 2016: 262). XI. yüzyılda Hakaniye Türkçesinde de kullanılmaya devam eden kelimenin taşıdığı anlam ise 'a piece of silk which a man keeps in his pocket the wipe his nose with // erkeklerin, burunlarını temizlemek için ceplerinde bulundurdukları ipek parçası' olarak verilmiştir. Günümüzde bu kelimenin kullanımı Türkmenlerde alatu 'a word for silk handkerchief // ipek mendil için kullanılan kelime’ biçimiyle devam etmektedir (ED 134b).

\section{6. züngüm}

"Bir tür Çin ipeğì" (Ercilasun ve Akkoyunlu, 2015: 243/211)

Clauson, kelimeyi hapax legomenon olarak verdikten sonra kelimenin Çinceden ödünçlendiğini belirtir ve barçın kelimesine gönderme yapar. Kelime XI. yüzyllda Hakaniye Türkçesinde züngü̈m biçiminde geçmekte olup 'a kind of Chinese brocade // bir tür Çin zerkeşi' anlamı taşımaktadır (ED 987b). Nadalyayev vd., kelimeyi züyüm biçiminde verdikten sonra kökeninin Çince olabileceği ihtimali üzerinde durur. Kelimenin açıklamasını ise 'вид китайской парчи // bir tür Çin sırmalı ipeği’ olarak yapar (DTS 640b). Räsänen de kelimeyi zügüm biçiminde verdikten sonra kökeninin Çince olduğunu belirtir. Kelimenin açıklamasını ise 'eine Art chinese Brokats // bir tür Çin sırmalı kumaşı' biçiminde yapar (VEWT 533a).

\section{Sonuç}

Dīvānu Lugāti’t-Türk, XI. yüzyıldaki Türk boylarının ağızları hakkında bilgiler veren diyalektolojik bir çalışma olmasının yanı sıra Türklere ait bazı efsaneleri, çeşitli âdet ve inanışları içine alan; eğlence, oyun, çalgı aletleri, avcılık, tarım, hayvancılık, ziraat, çeşitli sanatlar ve mesklekler, eşya adları ve gündelik kullanılan aletler, silahlar, at takımları, savaş aletleri, çeşitli yiyecek, içecek ve yiyecek adları, hastalıklar, tedavi şekilleri, ilaçlar, giyim kuşam, süslenme, kumaş adları ve türleriyle ilgili bilgiler veren bir halk bilimi eseridir. Bu eserde yer alan terimlerden çalışmamıza konu edindiğimiz "kumaş adları" gerek kumaş çeşitlerini görmemiz açısından gerek kumaşla ilgili söz varlığının zenginliği açısından çalışılmaya değer görülmüştür. XI. yüzyılda kumaşla alakalı kullanılan agı, ay, barçın, beçkem, bıçış, böz, çaydam, çek, çekrek, çınahsı, çit, çuz, egin, eşgürti, eşük, hulı刀, kaçaç, kamdu, keçe, kemek, kenzi, kerim, kez, kịdiz kidiz, kimişge, lohtay, mındatu, şalaşu, tahçek, tahtu, tanuk, tōnluk, torku, töşeklik, uyma, ületü, züngüm terimleri bize o dönemde kumaşın gündelik hayatta ne denli önem arz ettiğini göstermektedir. Eserde, tespit edilen

31 Clauson'a göre ület- kelimesinden türeyen kelime Atalay, Rustemov ve Kormuşin'de ulatu, Clauson, Dankoff ve Kelly'de ületü biçiminde geçmektedir. 
36 adet kumaş teriminin incelenmesiyle ortaya çıan muhtemel etimolojileri tablo biçiminde listeleyecek olursak;

1) Çince kökenli olarak tahmin edilenler; ay, çek ${ }^{32}$, çınahsı, çuz, eşgürti, kaçaç, kamdu, kenzi, lohtay, şalaşu, tahçek ${ }^{33}$, tahtu ${ }^{34}$, hultı, züngümm

2) Grekçe olarak tahmin edilenler; böz

3) İranî kökenli olarak tahmin edilenler; barçın, beçkem ${ }^{35}, \mathrm{kez}^{36}$

4) Moğolca, Farsça yahut başka bir dil kökenli olarak tahmin edilenler; torku $u^{37}$

5) Sanskritçe olarak tahmin edilenler; çit, mındatu

6) Türkçe olarak tahmin edilenler; agı, bıçış, çekrek, egin (Suvar Lehçesi), eşük, kerim, kidiz $\sim$ kidiz, kimişge $^{38}$, tōnluk, töşeklik, uyma ${ }^{39}$, ületü

7) Ödünçlenmiş olarak tahmin edilenler; keçe, kemek

8) Kökeni tespit edilemeyenler; çaydam, tayuk

O halde bir kelimenin Dīvānu Lugāti't-Türk'te geçmesi o kelimenin Türkçe kökenli olduğu anlamına gelmemektedir. Çünkü Dīvānu Lugāti't-Türk, Türkçe kelimelerin yanısıra başka dillerden ödünçlenen kelimeleri de barındıran ansiklopedik bir sözlük niteliği taşımaktadır. Bu geniş hacimli sözlükten bir kesit alarak incelediğimiz kumaş adlarıyla alakalı makalemizde yer alan kelimelerin etimolojisi üzerine farklı görüşler bulunmaktadır. Ayrıca bazı kelimelerin kökenleri tam olarak tespit edilememiş, bu kelimelerle ilgili çalışmalar etimolojik anlamda yetersiz kalmıştır. Bundan dolayı "ödünçlenmiş olarak tahmin edilenler" ve "kökeni tespit edilemeyenler" başlıkları altında sınıflandırdığımız çaydam, keçe, kemek, tayuk kelimeleri bir dil sınıfına dahil edilememiştir.

\title{
Kisaltmalar
}

\author{
BK K : Bilge Kagan, Kuzey \\ bkz. : : bakınız \\ BT VII : Fragmente tantrischer Werke in uigurischer Übersetzung, Kara-Zieme 1976 \\ DTS : : Dryeunyetyurkskiy Slovar', Nadalyayev-Nasilov-Tenişev-Şçerbak 1969 \\ ED : An Etymological Dictionary of Pre-Thirteenth-Century Turkish, Clauson 1972 \\ EDAL : An Etymological Dictionary of Altaic Languages, Starostin-Dybo-Mudrak 2003 \\ KB : Kutadgu Bilig \\ KMTS : : Karaçay-Malkar Türkçesi Sözlüğü, Tavkul 2000 \\ krş. : : karşılaştırınız \\ KTS : : Kazak Türkçesi Sözlüğü, Oraltay-Yüce-Pınar 1984
}

\footnotetext{
32 Sertkaya (2009: 18, 29) makalesinde kelimenin kökenini Giles’e göre Çince kökenli olarak kaydederken Dibo’ya göre Hotence veya Hoten Sakacası olarak kaydeder.

Sertkaya (2009: 21) makalesinde kelimenin kökeninin Çince olduğunu kaydeder.

Sertkaya (2009: 21) makalesinde kelimenin kökeninin Çince olduğunu kaydeder.

Sertkaya (2009: 29) makalesinde kelimenin kökeninin Hotence veya Hoten Sakacası olduğunu kaydeder.

Sertkaya (2009: 20) makalesinde kelimenin kökeninin Çince olduğunu kaydeder.

Sertkaya (2009: 27) makalesinde kelimenin kökeninin Moğolca olduğunu kaydeder.

Sertkaya (2009: 30) makalesinde kelimenin kökeninin Hotence veya Hoten Sakacası olduğunu kaydeder.

Sertkaya (2009: 27) makalesinde kelimenin kökeninin Moğolca olduğunu kaydeder.
} 


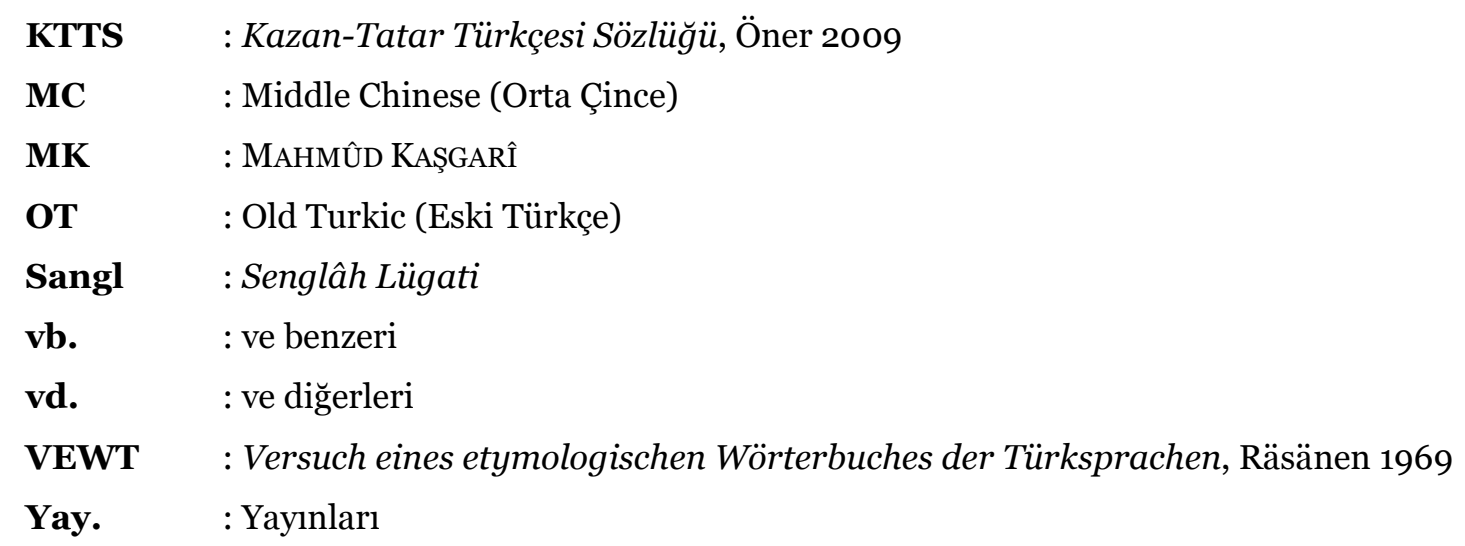

\section{Kaynaklar}

Abik, A. Deniz (2009). Kâşgarlı'dan Bugüne Anadolu Türkçesinde Akındı ve Egdü Yapısındaki Kelimeler, Akademik Araştırmalar Dergisi/Journal of Academic Studies (Kâş̧arl Mahmud Özel Sayısı), S. 39, s. 273-291.

Aksan, Doğan (2004). Türkçenin Sözvarlı̆̆ı. 3. Baskı, Ankara: Engin.

Alan, Sümeyra (2019). Dîvânu Lugâti't-Türk’te Spor ve Rekreatif Faaliyete İlişkin Terimler. Serhat Özdenk, Ozan Yılmaz (Ed.), Spor ve Rekreasyon Araştırmaları Kitabı-1.Cilt içinde, 86-109. Konya, Çizgi Kitabevi Yayınları.

Atalay, Besim (1985-1986). Divanü Lûgat-it-Türk Tercümesi I-IV. Ankara: Atatürk Kültür, Dil ve Tarih Yüksek Kurumu Türk Dil Kurumu Yayınları (AKDTYK. TDK Yay. 521-524).

Atalay, Besim (1970). Abuşka Lûgatı veya Çağatay Sözlüğü. Ayyıldız

Ayazlı, Özlem (2016). Eski Uygurca Din Dışı Metinlerin Karşılaştırmah Söz Varlığı. Ankara: Türk Dil Kurumu Yayınları (AKDTYK TDK Yay. 1187. Eski Uygurca Kütüphanesi 5).

Aydın, Erhan (2017). Orhon Yazıtları Köl Tegin, Bilge Kağan, Tonyukuk, Ongi, Küli Çor. İstanbul: Bilge Kültür Sanat.

Ayverdi, İlhan, Ahmet Topaloğlu (2011). Asırlar Boyu Tarihi Seyri İçinde Misalli Büyük Türkçe Sözlük. 2. Cilt. İstanbul: Kubbealtı Neşriyatı.

Boberg, Folke (1954-1955). Mongolian-English Dictionary. Stockholm, Förlaget Filadelfia AB, 3v PL 406 B $663 \mathrm{~m}$.

Bozkurt, Fuat (2012). (Uyarlama, Düzenleme, Çeviri): Kaşgarh Mahmud, Divan-ü Lūgat-it-Türk (Türk Dili Divanı). Konya: Eğitim.

Caferoğlu, Ahmet (1968). Eski Uygur Türkçesi Sözlüğü. Ankara: TDK.

Choi, Han-Woo (1992). Newly Identified Chinese Loan-words in Dīvānü Lugat-it-Türk. Central Asiatic Journal Vol. 36, No. 3/4 (1992), 188-198.

Clauson, Sir Gerard (1972). An Etymological Dictionary of Pre-Thirteenth-Century Turkish. Oxford at the Clarendon Press.

Coşar, Asiye, Bahadır Güneş (2011a). Açıklamalı Bir kaynakça Denemesi: Divânü Lugâti't-Türk ve Kâşgarlı Mahmud Üzerine Yazılan Makaleler. Journal of Turkology, 21(1), 167-231. Retrieved from https://dergipark.org.tr/tr/pub/iuturkiyat/issue/18515/195250

Coşar, Asiye, Bahadır Güneş (2011b). Açılkamalı Bir Kaynakça Denemesi-II: Divânü Lugâti't-Türk ve Kâşgarlı Mahmud Üzerine Hazırlanan Bildiriler. Journal of Turkology, 21(2), 19-86. Retrieved from https://dergipark.org.tr/tr/pub/iuturkiyat/issue/18516/195294

Çifci, Musa, Talip Yıldırım (2012). Divanü Lugati-t-Türk'te Yer Alan Alet-Eşya Adları. Turkish StudiesInternational Periodical For The Languages, Literature and History of Turkish or Turkic. (7) 2, 1229-1249. 
Pavet de Courteille, Abel (1820). M. Dictionnaire Turc-Oriental. Paris.

Dankoff, Robert, James Kelly (1982-1985). Mahmūd al Kāšyarī. Compedium of Turkic Dialects (Dīwān Luyāt at-Turk). Part I-III. Duhbury, Massachusetts: Harvard University. (Sources of Oriental Languages and Literatures. 7. Turkish Sources. VII.)

Dağll, Barış (2007). Kelime Kazanımı Üzerinde Bir Araştırma (Kıyafet ve Kumaş Adları Örneği). Yayımlanmamış Yüksek Lisans Tezi, Marmara Üniversitesi, Eğitim Bilimleri Enstitüsü, Türkçe Eğitimi Anabilim Dah, İstanbul.

Doerfer, Gerhard (1965). Türkische und mongolische Elemente im neupersischen. Unter besonderer Berücksichtigung älterer neupersischer Geschichtsquellen, vor allem der Mongolen- und Timuridenzeit. 2. Türkische Elemente im Neupersischen: alif bis tā. Wiesbaden. (Akademie der Wissenschaften und der Literatur [Mainz]. Veröffentlichungen der Orientalischen Kommission. 19).

Doerfer, Gerhard (1975). Proto-Turkic: reconstruction problems. Türk Dili Araştırmaları Ylllı̆glBelleten, 23(1975-1976), 1-59.

Ecsedy, Hilda (1975) Böz - An Ehotic Cloth in the Chinese Imperial Court, in: Altorientalische Forschungen (AoF) 3(1975), 145-153.

Ercilasun, Ahmet Bican, Ziyat Akkoyunlu (2015). Kâşgarlı Mahmûd Dīvānu Lugāti’t-Türk (Giriş -Metin -Çeviri-Notlar-Dizin). 2. Baskı. Ankara: TDK.

Erdal, Marcel (1991). Old Turkic Word Formation. A Functional Approach to the Lexicon, I-II, Wiesbaden: Harrassowitz.

Genç, Reşat (1998). Kaşgarlı Mahmud'a Göre XI. Yüzyılda Türklerde Dokuma ve Yaygı İşleri. Arış Dergisi, (3), 8-17.

Güner, Galip (2016). Eski Türkler Çek Yazar Mıydı? Uluslararası Türkçe Edebiyat Kültür Eğitim (TEKE) Dergisi, 5(1), 34-41.

Halıcı, Feyzi (1993). Çevgân, Diyanet İslam Ansiklopedisi, İstanbul, 4. Cilt, 294.

Kara, Georg, Peter Zieme (1976). Fragmente tantrischer Werke in uigurischer Übersetzung. Berlin. (AdW der DDR. ZAGA. SGKAO. BT. 7.)

Karaağaç, Günay (1998). Türkçenin Komşu Dillere Verdiği Giyim Kuşam Kültürüyle İlgili Kelimeler. Türk Dili, 5, 361-387.

Karahan, Akartürk (2009). Dīvānu Luġāti’t-Türk’e Göre XI. Yüzyıl Türk Lehçe Bilgisi. Yayımlanmamış Doktora Tezi, Ankara Üniversitesi, Sosyal Bilimler Enstitüsü, Türk Dili ve Edebiyatı Anabilim Dalı, Ankara.

Karaman, Ahmet (2003). Yeni Uygur Türkçesinde Kullanılan Giyecek Adları. Dünya Dili Türkçe, 133142.

Küçük, Saim (2010). Eski Türk Kültüründe Renk Kavramı. Bilig, Yaz 2010, Sayı 54: 185-210.

Lessing, Ferdinand D. [ed.] (1960). Mongolian-English Dictionary. Bloomington.

Maralbek Yermukhamet, Muhammet Koçak (2018). Kaşgarlı Mahmut'un Divanu Lügati't-Türk Adlı Eserinde Yer Alan Ölçü Birimleri. Türk Kültürü ve Hacı Bektaş Veli Araştırma Dergisi, 8(187199).

Miller, Roy A. (2005). Turkic böz 'fabric' in Korea and Japan. Studia Turcologica Cracoviensia No. 10, 279-287.

Monier-Williams, Monier (1899). A Sanskrit-English Dictionary. Oxford: Oxford Universty Press.

Nadalyayev V. M, D. M. Nasilov, E. R. Tenişev, A. M. Şçerbak (1969). Dryevnyetyurkskiy Slovar'. Leningrad: Akademiya Nauk.

Oraltay, Hasan, Nuri Yüce, Saadet Pınar (1984), Kazak Türkçesi Sözlüğü, İstanbul: Türk Dünyası Araştırmaları Vakf Yayım. 
Ölmez, Mehmet (1992). Uygurca üçük ‘kürk'. Türk Dilleri Araştırmaları, 47-52.

Ölmez, Mehmet (2008). Eski Türk yazıtlarındaki eşük, kedimlig ve teve Üzerine, Festschrift in Honor of Talat Tekin / Türk Dilleri Araşttrmalarl 18(2008), 333-340.

Öner, Mustafa (2009). Kazan-Tatar Türkçesi Sözlüğü, Ankara: Türk Dil Kurumu Yayınları.

Özyetgin, A. Melek (2004). Eski Türklerde Ödeme Araçları: kâğıt para çav'ın kullanımı. Modern Türklük Araştırmaları Dergisi, 1(1), 90-105.

Poppe, Nicholas (2016). Moğol Yazı Dilinin Grameri (Çeviren: Günay Karaağaç). Ankara: TDK.

Ramstedt, Gustaf John (1935). Kalmückisches Wörterbuch [Lehica Societatis Fenno-Ugricae 3]. Helsinki: Suomalais-ugrilainen seura.

Raschmann, Simone Christiane (1995). Baumwolle im türkischen Zentralasien. Philologische und wirtschafttshistorische Untersuchungen anhand der vorislamischen uigurischen Texte. Wiesbaden: Harrassowitz Verlag (Veröffentlichungen der Societas Uralo-Altaica 44).

Raschmann, Simone Christiane (2008). Baumwoll-Nachlese: Vier alttürkische böz-Dokumente aus dem ARAT-NachlaB (lstanbul). 内陸アジア言語の研究, 23, 121-150.

Räsänen, Martti (1969). Versuch eines etymologischen Wörterbuches der Türksprachen. 2. Wortregister. Zusammengestellt von István Kecskméti. Helsinki. (Lehica Societatis FennoUgricae. 17, 1.)

Róna-Tas, András (1975). "Böz in the Altaic World”, in: AoF 3(1975), 155-163.

Rozycki, William (1994). Mongol elements in Manchu (Vol. 157). Indiana University Research Institute for Inner Asian Studies.

Sertkaya, Osman Fikri (2009). Dîvânü Lügati't-Türk’te Geçen Her Kelime Türkçe Kökenli midir? veya Kâşgarlı Mahmud'un Dîvânü Lügati't-Türk'ünde Yabancı Dillerden Kelimeler. Dil Araştırmalart, 5(5), 9-38.

Sevortyan E. Viladimiroviç (1974-1997). Etimologiçesky Slovar' Tyurskih Yazıkov (1. 1974, II. 1978, III. 1980, IV. 1989, V. 1997). Obşçetyurkskie i meztyurkskie osnovy na glasnye. Moskva: Izdatelstvo Nauka.

Starostin, Sergei, Anna Dybo, Oleg Mudrak with assistance of Ilya Gruntov and Vladimir Glumov (2003). Etymological Dictionary of the Altaic Languages, I-III: Leiden-Boston: Brill (Handbook of Oriental Studies)

Steingass, F[erdinand] (1982). A Comprehensive Persian-English Dictionary: Including the Arabic Words and Phrases to be met with in Persian Literature, Being, Johnson and Richardson's Persian, Arabic and English Dictionary, Librairie du Liban Publishers, London.

Şahin, Hatice (2006). Terimlerin Genel Dile Yansımasına Dair Bazı Gözlemler. Erciyes Üniversitesi Sosyal Bilimler Enstitüsü Dergisi. 1 (20), 123-129.

Tavkul, Ufuk (2000). Karaçay-Malkar Türkçesi Sözlüğü. Ankara: TDK Yayınları.

Tekin, Talat (2006). Orhon Yazıtları. 2. Baskı. Ankara: Türk Dil Kurumu Yayınları (AKDTYK. TDK Yay. $540)$.

Tekin, Şinasi (1980). Maitrisimit nom bitig: Die uigurische Übersetzung eines Werkes der buddhistischen Vaibhāşika-Schule. 1. Transliteration, Übersetzung, Anmerkungen. 2. Analytischer und rückläufiger Indeh. Berlin: Akademie-Verlag.

Uçar, Erdem (2017). Sir Gerard Clauson'un Sözlüğündeki ‘Muhtemel Etimolojiler’ Üzerine. Journal of Old Turkic Studies, 1(2), 74-90.

Usmanova, Shoira (2011). Altay Dillerinde Üst Giysi Adları. Türk Dünyası İncelemeleri Dergisi, 11 (1), 15-23.

Vámbéry, Ármin (1862). Abuska: Csagatajtörök szógyüjtemény. Emich Gusztáv M. Akad. Nyomdász Betüivel. 
Vovin, Alehander (2018). Fabrication of Turkic böz 'fabric'in Japan and Korea. Acta Orientalia Academiae Scientiarum Hungaricae, 71(3), 263-284.

Yamada, Nobuo (1993). Sammlung Uigurischer Kontrakte, 3 vols. Ed. by J. Oda / P. Zieme / H. Umemura / T. Moriyasu. Osaka.

Yusuf Has Hâcip (1985). Kutadgu Bilig I (Çeviren: Reşit Rahmeti Arat). Ankara: Türk Tarih Kurumu Yayınları.

Zieme, Peter (1976). Zum Handel im Uigurische Reich von Qoço, Altorientaliche Forscungen 4, 235249.

Zieme, Peter (1985). Buddhistische Stabreimdichtungen der Uiguren. Berlin: Akademie-Verlag.

Zieme, Peter (1997). 'Silk’and 'Wad’in Old Turkish Terminology. Türk Dilleri Araştırmaları, 7, 149-155. 